\title{
Antimicrobial Activity of Cymbopogon citratus (Dc) Stapf (Lemongrass) Essential Oil on Pathogenic Bacteria From Fruit Juices
}

Caroline Junqueira Barcellos Leite (I), Jossana Pereira de Sousa (II), Kataryne Árabe Rimá de Oliveira (I), Geany Targino de Souza (I), Danilo Elias Xavier (I), Maria Lucia da Conceição (I), Vivyanne dos Santos Falcão Silva (I), Evandro Leite de Souza (I)

(I) UFPB - Federal University of Paraíba (Cidade Universitária, s/n - 58051-900 - Castelo Branco, João Pessoa - PB, Brazil), (II) UFPE - Federal University of Pernambuco (Av. Prof. M. Rego - Cidade Universitária, s/n - 50670-901, Recife - PE, Brazil)

\section{Resumo}

Because the consequences of microbial growth in fruit juice become necessary the adoption of preventive actions with emphasis on the use of conservation methods for reducing the number of micro-organisms and/or decrease their growth rate in these products, however maintaining the proper characteristics of the product. Considering the trends in food conservation technology, which have given importance for the of essential oils as antimicrobials in foods, the aim of this study was to evaluate the antimicrobial effect of the essential oil from Cymbopogon citratus (DC) Stapf (lemongrass) against some pathogenic bacteria commonly found as contaminants in fruit juices. The lemongrass essential oil was obtained from Laszlo Aromateraia Ltda; strains of Escherichia coli (UFPEDA 224) and Salmonella enteritidis (UFPEDA 414) were obtained from Department of Antibiotics/UFPE (Recife/PE) and Listeria monocytogenes (INCQS 7644) were obtained from National Institute of Quality Control in Health (Rio de Janeiro/RJ). The antimicrobial activity of the essential oil was evaluated by determining the minimum inhibitory concentration (MIC) using the microdilution in broth technique as recommended by the Clinical and Laboratory Standards Institute (CLSI). For this, the strains were grown

\footnotetext{
Referência:

Caroline Junqueira Barcellos Leite, Jossana Pereira de Sousa (II), Kataryne Árabe Rimá de Oliveira, Geany Targino de Souza, Danilo Elias Xavier, Maria Lucia da Conceição, Vivyanne dos Santos Falcão Silva, Evandro Leite de Souza. Antimicrobial Activity of Cymbopogon Citratus (Dc) Stapf (Lemongrass) Essential Oil on Pathogenic Bacteria From Fruit Juices. In: Anais do 12 Congresso Latinoamericano de Microbiologia e Higiene de Alimentos - MICROAL 2014 [= Blucher Food Science Proceedings, num.1, vol.1]. São Paulo: Editora Blucher, 2014. DOI 10.5151/foodsci-microal-327
} 
in BHI broth separately $\left(37^{\circ} \mathrm{C} / 24 \mathrm{~h}\right)$, with subsequent standardization of suspensions using $0.5 \mathrm{MacFarland}$ scale $\left(10^{8} \mathrm{CFU} / \mathrm{mL}\right)$, following by adjusting the inoculum to $5 \times 10^{5} \mathrm{CFU} / \mathrm{mL}$ and finally preparing the mixed inoculum (1:1:1). Thereafter, $50 \mu \mathrm{L}$ of suspensions were inoculates in microplates containing $50 \mu \mathrm{L}$ of BHI broth added of bacteriological agar $(0.15 \%)$ and of the assayed essential oil at different concentration (1.25 to $80 \mu \mathrm{L} / \mathrm{mL})$. After the incubation period $\left(37^{\circ} \mathrm{C} / 24 \mathrm{~h}\right)$, the verification of bacterial growth was performed by adding $20 \mu \mathrm{L}$ of Resazurin (0.01\%), and the MIC as the lowest essential oil dilution which no microbial growth was observed. The MIC value of lemongrass essential oil against $S$. enteritidis was $10 \mu \mathrm{L} / \mathrm{mL}$; while against E. coli and L. monocytogenes was $5 \mu \mathrm{L} / \mathrm{mL}$. MIC value of lemongrass essential oil against the mixed inoculum was $5 \mu \mathrm{L} / \mathrm{mL}$. The antimicrobial property presented by the lemongrass essential oil against the pathogenic bacteria tested suggest its possible use as an antimicrobial substance for controlling the growth and survival of fruit juice related-pathogenic bacteria.

Palavras-Chave: Antimicrobial activity, Essential oil, Fruit juices, Lemongrass, Pathogenic bacteria

Agência de Fomento: 